\title{
3 From hot waters of polar seas: the mysterious life of the male yeti crab
}

4

5 Sven Thatje*, Leigh Marsh

6

7 Ocean and Earth Science, University of Southampton, National Oceanography Centre

8 Southampton, Waterfront Campus, Southampton SO14 3ZH, UK

9

\section{*Email: svth@noc.soton.ac.uk}

In 2010, a new biogeographic province of hydrothermal vent fauna was discovered on the East Scotia Ridge (ESR), Southern Ocean, situated to a maximum depth of 2,600 m (Rogers et al. 2012). Two hydrothermal vent fields, named E2 and E9, were found on the northern and southern branch of the ESR, respectively. The chemosynthetic dependent benthic macrofauna that dominate these sites were new to science, and many of the species appear to be endemic to the Southern Ocean province. A member of the enigmatic family of Kiwaidae commonly known as yeti crabs or squat lobsters - visually dominates the vent fauna (Fig. 1A-C) (Marsh et al. 2012, Rogers et al. 2012). This species, Kiwa tyleri, sustains itself on chemosynthetic bacteria, which grow on two types of specialized setae that cover the ventral side of its carapace and pereopods in dense rows (Thatje et al. 2015a, b). For the majority of individuals, their habitat is limited to a thermally well-defined, narrow envelope of warm-water surrounding the hydrothermal vent system, bound in the cold temperatures of the deep Southern Ocean, which were found to be as cold as 0 and $1.3^{\circ} \mathrm{C}$ at $\mathrm{E} 2$ and $\mathrm{E} 9$, respectively. Under the high pressures and low temperatures of the surrounding deep sea, the temperature of hydrothermal fluids emanating from "black smoker" chimneys can reach up to $380^{\circ} \mathrm{C}$, but will drop to cold, ambient temperatures of the surrounding deep sea within a few centimeters. This provides any warm-adapted organism dependent on chemosynthetic nutrition with a very limited three-dimensional thermal envelope surrounding the vents. In this con- text, it should be highlighted that most anomuran crabs possess high $\mathrm{Mg}^{2+}$ levels in their hemolymph which, in com- bination with low polar temperatures $\left(<0.5^{\circ} \mathrm{C}\right)$ lead to a paralyzing state that will not allow them to sustain life in polar seas 
28 (Aronson et al. 2015). Therefore, Kiwa tyleri are thermally isolated in their habitat and may have been so since

29 their radiation into the Southern Ocean during the process of Antarctic Cooling in the Miocene, some 13-25 Ma

30 ago (Roterman et al. 2013, 2018).

31 The limited habitat available for growing chemosynthetic bacteria may have caused Kiwa tyleri to express several

32 adaptations that are unusual of squat lobsters if not anomuran crabs in general. Kiwa tyleri aggregate in large

33 numbers of up to 700 specimens per square meter (Marsh et al. 2012), mostly in the vent fluids of the lower parts

34 of vents and at the base of chimneys in order to grow chemosynthetic bacteria (Zwirglmaier et al. 2015). They

35 occur segregated by size (age) and sex, and in doing so optimize the use of avail- able space, maximizing the number of specimens in the available habitat (Fig. 1B) (Marsh et al. 2015). Such dense aggregations in some species of anomuran crab are usually only found at specific times of the life cycle, such as during molt - when there is security in numbers - and during reproduction.

However, there are also exceptionally large males that are found in very low numbers (single specimens to few dozens), in the mostly upper parts of vent chimneys, where temperatures tend to be much higher than the approximately 2 to $15^{\circ} \mathrm{C}$ at the vent base. These males reach a size of about $7-10 \mathrm{~cm}$ of carapace length, compared to $<5.5 \mathrm{~cm}$ of carapace length in smaller males and females in Kiwa aggregations (Marsh et al. 2015, Thatje et al. 2015a, b). A preliminary study of thermal tolerance using an experimental high-pressure system (IPOCAMP,

44 Shillito et al. 2014) at sea has found large males to tolerate temperatures of up to at least $27^{\circ} \mathrm{C}$ (S. Thatje, unpublished data) and visual evidence would suggest that individuals can come into contact with even higher temperatures, at least for short periods of time (Fig. 1C, see also supplementary video 3 in Marsh et al. 2015).

It remains unknown why so few of these large males venture away from the uppermost parts of the hydrothermal chimneys, or what their ecological role may be. Indeed, large females are not found at all, which may be due to the circumstance that brooding females of smaller $(<5.5 \mathrm{~cm})$ cara- pace length leave to brood their young away from the short vicinity of vents and in order to hatch their lecithotrophic larvae away from the toxic vent fluids.

51 It has been suggested that females do not return to the vent environment, but die after such prolonged period of 52 brooding in cold Southern Ocean waters and in the absence of any food supply (Thatje et al. 2015a). By the end of the brooding period, the female crab is in a very deteriorated physical state often showing signs of necrosis of the carapace and pereopods (Marsh et al. 2015, Thatje et al. 2015a). 
55 Whether the size of large males is due to older age and/or simply to higher metabolic rates and consequently 56 greater growth rates in the warmer waters of chimney systems is unknown. Away from Kiwa aggregations, 57 however, there tend to be carpets of chemosynthetic bacteria on uppermost parts of the chimneys, which could 58 provide the additional energy needed for large males to grow under these conditions of greater metabolic demand.

59 Some brush-like setae used by Kiwa tyleri to harbor chemosynthetic bacteria can also be used to sweep up bacteria 60 from surfaces (Thatje et al. 2015a, b). But what is the ecological role of these few large males and why are they 61 generally found in isolation from smaller size classes? Although Kiwa tyleri living in aggregations appear not to 62 show any major expression of aggressive competitive behaviors toward conspecifics, individual males of similar 63 size have repeatedly been found fighting by pushing each other using their large chelae (see supplementary video 641 in Marsh et al. 2015). Their levels of aggression may explain why smaller males have not been found in areas 65 of large male dominance, and this might explain why large areas of chimneys covered in bacterial car- pets potentially providing food, are free of any high-abundance Kiwa tyleri aggregations.

67 Still, what is the role of the size dimorphism found in this species? A clue to this might be found in the reproductive behavior of squat lobsters, which to date has not been observed in any yeti crab. Unlike many other anomuran crabs, female squat lobsters do not need to molt to be receptive (Thiel and Lovrich 2011). Generally, the male approaches the female and dorsally embraces her by grasping the female using pereopod or chela to keep her in a pre- copulatory position that in many galatheid squat lobster species can last days to weeks (Thiel and Lovrich 2011). In anomuran crabs, the male chelae are often used to hold on to the chela or first pereopod pair of the female. The male of a mating couple tends to be about $1 / 4$ to $1 / 3$ larger in size than the female; however, this does generally not seem to be the case in galatheid squat lobsters. Should large males of Kiwa tyleri be involved in reproduction, however, their larger size would present a perfect cavity when embracing a much smaller female (see Fig. 1A) protecting her from other males. Furthermore, the presence of a comb of strong, flattened, teeth-like spines (from ischium to carpus) of the chela, which are greatly enlarged in larger males when com- pared to smaller males and females, allows the dominant male to arrest the female on its lateral margins of the carapace (Thatje et al. 2015a, b) during precopulatory embrace, keeping her in place. Given the comparatively low number of large males and the high abundance of females in the population, and in order to play an evolutionary advantage of size in reproduction at population level, males would need to be able to mate multiple times. However, this hypothesis requires further investigation. 
83 In addition to rivalry for optimum space on the vent chimney, competition for females must be fierce during mat-

84 ing season: as the aggregation of mature Kiwa tyleri segregated by sex dissolves by changes in their hormonal

85 state at the onset of the reproductive season, more space for potentially long periods of precopulatory

86 embracement is needed. This is the time when the entirety of the inhabitable vent environment- even the large

87 male dominated parts - may need to be populated, or specimens of Kiwa tyleri may be pushed away from the

88 favorable thermal environment of the vent and die. In order to test the hypothesis that space com- petition during

89 reproduction leads to high mortality in males, long-term monitoring of Kiwa tyleri, ideally by using an in situ

90 time-lapse camera system is required. This would also clarify whether the smaller males are outcompeted by large

91 ones. Indeed, should large males successfully defend their territory against smaller ones during mating season,

92 then it is most likely that many of the smaller males are being excluded from reproduction or even pushed away

93 from the vent environment, in which case smaller males might experience high mortalities. Given the competitive

94 situation of the vent environment, being large may even be prerequisite for males to be able to mate successfully.

95 Com- petition for the right to mate would also explain why there are comparatively few larger males at these

96 vents, as they are the survivors of this selection process. Furthermore, aggressions between smaller and large

97 males in competition for females could easily lead to smaller males being crushed in a precopulatory embracement

98 position with a larger male and by its teeth-like, strongly serrated structures of the chela (Fig. 1A). To conclude,

99 the limited size vent habitat makes it necessary that co-existence among conspecific of Kiwa tyleri prevails;

100 selection on the male genotype, however, may be particularly severe among mature males. Space limitation

101 dominates the evolution of life history in the Antarctic yeti crab.

\section{ACKNOWLEDGEMENTS}

103 We thank the Master, crew, and Scientific Party of the RRS James Cook for their support during the fieldwork in 104 the Southern Ocean on the cruise JC42. We also thank the staff of National Mar- ine Facilities at the National

105 Oceanography Centre, Southampton, for logistic and shipboard support and the pilots and technical teams of the

106 Isis ROV. We thank Gustavo A. Lovrich and Klaus Anger for constructively commenting on the manuscript. The

107 ChEsSo research programme was funded by a NERC Consortium Grant (NE/DO1249X/1). This is a ChEsSo

108 publication. 
110 Aronson, R. B., M. Frederich, R. Price, and S. Thatje. 2015. Pro- spects for the return of shell-crushing crabs to

111 Antarctica. Journal of Biogeography 42:1-7.

112 Marsh, L., J. T. Copley, V. A. I. Huvenne, K. Linse, W. D. K. Reid, A. D. Rogers, C. J. Sweeting, and P. A. Tyler.

113 2012. Microdistribution of faunal assemblages at deep-sea hydrothermal vents in the Southern Ocean. PLoS ONE

$114 \quad 7: \mathrm{e} 48348$.

115 Marsh, L., J. T. Copley, P. A. Tyler, and S. Thatje. 2015. In hot and cold water: differential life-history adaptations

116 are key to success in contrasting thermal deep-sea environments. Journal of Animal Ecology 84(4):898-913.

117 Rogers, A. D., et al. 2012. The discovery of new deep-sea hydrothermal vent communities in the Southern Ocean

118 and implications for biogeography. Plos Biology 10:e1001234.

119 Roterman, C. N., J. T. Copley, K. Linse, P. A. Tyler, and A. D. Rogers. 2013. The biogeography of the yeti crabs 120 (Kiwaidae) with notes on the phylogeny of the Chirostyloidea (Decapoda: Anomura). Proceedings of the Royal 121 Society B- Biological Sciences 280:20130718.

122 Roterman, C. N., W.-K. Lee, X. Liu, R. Lin, X. Li, and Y.-J. Won. 2018. A new yeti crab phylogeny: Vent origins 123 with indications of regional extinction in the East Pacific. PLoS ONE 13:e0194696.

124 Shillito, B., F. Gaill, and J. Ravaux. 2014. The IPOCAMP pressure incubator for deep-sea fauna. Journal of 125 Marine Science and Technology 22:97-102.

127 Thatje, S., L. Marsh, C. N. Roterman, M. N. Mavrogordato, and K. Linse. 2015a. Adaptations to hydrothermal 128 vent life in Kiwa tyleri, a new species of yeti crab from the East Scotia Ridge, Antarctica. PLoS ONE 10. 129 https://doi.org/10.1371/journal.pone. 0127621.

130 Thatje, S., K. E. Smith, L. Marsh, and P. A. Tyler. 2015b. Evidence for abbreviated and lecithotrophic larval 131 development in the yeti crab Kiwa tyleri from hydrothermal vents of the East Scotia Ridge, Southern Ocean. Sexuality and Early Development in Aquatic Organisms 1:109-116. 
133 Thiel, M. and G. A. Lovrich. 2011. Agonistic behaviour and repro- ductive biology of squat lobsters. Pages 223-

134247 in G. C. B. Poore, S. T. Ahyong, and J. Taylor, editors. The biology of squat lobsters. CRN Press, 135 Collingwood, Australia.

136 Zwirglmaier, K., W. D. K. Reid, J. Heywood, C. J. Sweeting, B. Wig- ham, N. V. C. Polunin, J. A. Hawkes, D.

137 P. Connelly, D. Pearce and K. Linse. 2015. Linking regional variation of epibiotic bacte- rial diversity and trophic 138 ecology in a new species of Kiwaidae (Decapoda, Anomura) from East Scotia Ridge (Antarctica) hydrothermal 139 vents. Microbiology Open, 4:136-150.

140 Manuscript received 30 May 2018; revised 29 June 2018; accepted 10 July 2018. Corresponding Editor: John 141 Pastor. 

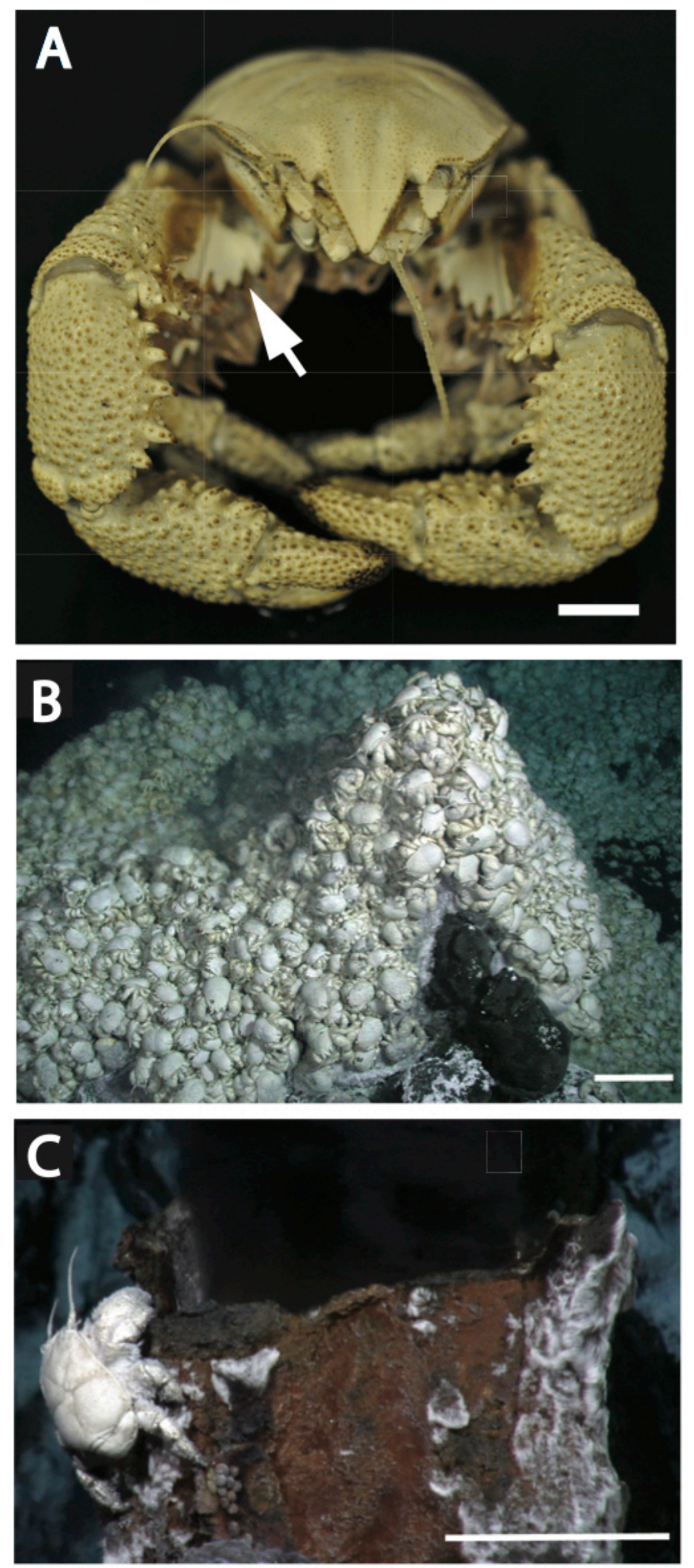
144 FIG. 1. Kiwa tyleri Thatje et al. (2015a, b) at hydrothermal vents on the East Scotia Ridge, Southern Ocean. (A)

145 Frontal view of a large male of Kiwa tyleri (carapace length $=6.7 \mathrm{~cm}$ ); arrow indi- cates comb of strong,

146 flattened, teeth-like spines (from ischium to carpus) which appear greatly enlarged in large males (Thatje et al.

147 2015a, b). (B) A high-density assemblage of Kiwa tyleri at the base of hydrothermal vent (E9 vent field, Rogers

148 et al. 2012). (C) Individual male of Kiwa tyleri at the orifice of a hydrothermal vent "black- smoker" fluid exit

149 (E2 vent field) (see also supplementary video 3 in Marsh et al. 2015). Scale bar: $1 \mathrm{~cm}$ (A), $10 \mathrm{~cm}$ (B), $5 \mathrm{~cm}$ (C) 